\title{
Somut Olmayan Kültür Miras Listesinde Bir Değer Olan Türk Kahvesine Coğrafya Perspektifinden Bakış
}

\author{
Nusret KOCA * \\ Arzu ERSÖZ TÜĞEN **৫
}

Öz

Bu çalışmada 2013 yılında UNESCO tarafında somut olmayan kültürel miras listesine alınan Türk Kahvesi, coğrafya ilminin esaslarına göre değerlendirilmeye çalışılmıştır. Anadolu’nun iklim koşullarına uygun bir bitki olmadığı halde Türkiye’de çok fazla tüketilen ve Türk Kahvesi adı altında tescillenen bu içecek, Türk insanının günlük ritüellerinin, gelenek ve göreneklerinin de merkezine yerleșmiștir. Anadolu topraklarında yaklașık olarak 500 yıllık bir geçmiși olan Türk Kahvesini dünyadaki diğer benzerlerinden ayıran en önemli özellik, telvesi ile ikram edilmesi ve pişirme şeklinin diğer kahvelerden farklı olmasıdır. Esas anavatanı bugünkü Etiyopya olan kahvenin Anadolu’ya geliși Mekke ve Medine’de dini görevlerini yapan hacılar tarafından olduğu tahmin edilmektedir. Osmanlı Devleti’nin başkenti olan İstanbul'a gelmesinin ise Yemen Valisi olan Özdemir Paşa tarafından gerçekleştirildiği bilinmektedir.

Sosyal bilimler içinde yer alan birçok disiplinde Türk kahvesi incelenmiştir. Ortak kültürümüze ait pek çok değeri içeren Türk Kahvesi gerek içildiği mekân gerekse tarihi, davranışsal ve ekonomik yönleri ile beşerî coğrafyanın ilgi alanına girmektedir. Çalışmada Türk Kahvesi coğrafyanın temel unsuru olan mekân ve insan perspektifinden incelenmiștir. Bu amaçla nitel araştırma yöntemlerinden olan doküman analizi yapılmış, konu ile ilgili geniş literatür çalışması yapılmıştır. İthal bir ürün olan kahvenin tüketimindeki hızlı artışa paralel olarak Türkiye’nin iklim şartlarında yetișen bitki kahvelerinin de (menengiç, kendir, çörekotu ve nohut) son yllarda oldukça popüler olduğu tespit edilmiştir.

Anahtar Kelimeler: Somut Olmayan Kültürel Miras, Türk Kahvesi, Kahve Kültürü, UNESCO, ICO Jel Kodu: Z10

\section{A View of Turkish Coffee, a Value in the Intangible Cultural Heritage List, from a Geographical Perspective}

\author{
Abstract

\footnotetext{
* Prof. Dr., Afyon Kocatepe Üniversitesi, Eğitim fakültesi, ORCID ID: 0000-0002-1415-9683 nkoca@aku.edu.tr

- Sorumlu Yazar

** Doktora Öğrencisi, Afyon Kocatepe Üniversitesi, Sosyal Bilimler Enstitüsü, ORCID ID: 0000-0002-2726-2065 arzuaygunt@hotmail.com
}

In this study, Turkish Coffee, which was included in the intangible cultural heritage list by UNESCO in 2013, was tried to be evaluated according to the principles of geography. Anatolia's climatic conditions suitable plant despite not being too much of these drinks consumed in Turkey and registered under 
the name of Turkish coffee, the daily ritual of the Turkish people, is located at the center of their traditions and customs. The most important feature that distinguishes Turkish coffee, which has a history of approximately 500 years in Anatolian soil, from other similar ones in the world is that it is served with grounds and its cooking style is different from other coffees. It is estimated that coffee, whose main homeland is today Ethiopia, comes to Anatolia by pilgrims who perform their religious duties in Mecca and Medina. It is known that Özdemir Pasha, the Governor of Yemen, came to Istanbul, the capital of the Ottoman State.

Turkish coffee has been studied in many disciplines within the social sciences. Turkish Coffee, which contains many values belonging to our common culture, is in the interest of human geography with its location, history, behavioral and economic aspects. In the study, Turkish Coffee was examined from the perspective of space and human, which is the main element of geography. For this purpose, document analysis, which is one of the qualitative research methods, was made and extensive literature study was conducted on the subject. In parallel with the rapid increase in the consumption of coffee is also a product imported coffee plants grown in Turkey's climatic conditions (turpentine, hemp, black cumin) has been found to be quite popular in recent years.

Keywords: Intangible Cultural Heritage, Turkish Coffee, Coffee Culture, UNESCO, ICO Jel Code: Z10

\section{GIIRIș}

Bir neslin kendinden sonraki kuşağa bıraktığı şey olarak tanımlanan miras kavramının içine kültürel öğelerin de eklenmesiyle oluşan kültürel miras unsurları toplumsal değerler açısından son derece önemlidir (TDK; Ulusoy, 2011: 160). Toplum tarafından benimsenmiş ve topluma mal olmuş olan değerleri kuşaktan kuşağa aktararak oluşturulan kültürel miras, insanların kenetlenmesini sağlayan bir nevi çimento görevini görmektedir.

İkinci Dünya Savaşı gibi milletlerin hafızasında son derece yıkıcı izler bırakan ve kültürel mirasların talan edildiği bir savaştan sonra kurulan UNESCO, kültürlerin korunmasını ilk olarak somut değerler üzerinden başlatmıştır. Dünya Kültürel ve Doğal Mirasın Korunması Sözleşmesi kapsamında 1972 yılında ilk olarak koruma altına alınan ve ilk göze çarpan unsurlar somut miraslardır (Oğuz, 2016: 3; Özkan, 2020: 361). Bunlar tarihi şehirler, su yolları, tarihi rotalar, heykeller, anttlar, sit alanları, kütüphaneler gibi geçmiş neslin oluşturduğu ve gelecek nesle aktarılması gereken unsurlardı. 2003 yılında ise toplumun bir arada yaşaması sonucunda oluşmuş kültürel değerler içinde yer alan gelenek, görenek, örf ve adetler ile geleneksel el sanatları, mutfak kültürü, geleneksel müzik ve danslardan oluşan somut olmayan miras çatısı içinde toplanan unsurlar kültürel miras olarak değerlendirilmiştir (Diker ve Deniz, 2017: 16; Özgürel, 2018: 4895). Türkiye 2006 yılında sahip olduğu birtakım kültürel değerleri sunarak bu anlaşmaya müdahil olmuştur.

Türkiye gerek somut gerekse somut olmayan kültürel miras açısından son derece zengin bir ülkedir. UNESCO’nun toplam olarak 1121 olarak belirlediği miras değerleri listesinden 18'si Türkiye’ye aittir. 18 mirastan 16'sı kültürel, 2'si karmadır. Somut olmayan kültürel miras listesinde de Türkiye’ye ait 18 kültürel değer yer almaktadır (http://www.unesco.org. tr/Pages/125/122/UNESCO-D\%C3\%BCnya-Miras\%C4\%B1-Listesi). Bu kültürel değerler 
içinde yer alan ve 2013 yılında Türk adı ile tescillenen kahve, çalışmamızın esas konusunu oluşturmaktadır. Türk geleneksel hayatında önemli bir yer işgal eden kahvenin tarihi, kültürel, ekonomik ve davranışsal anlamda pek çok alanı etkileyen özellikleri vardır. Çalışmamızda bu özellikler coğrafya ilminin nedensellik, bağlantı ve dağılış ilkeleri esasına göre incelenmiştir. Bu amaçla nitel araştırma yöntemlerinden olan gözlem ve doküman analizi yapılmıştır.

\section{KAHVE AĞACI}

Ekvatorun $25^{\circ}$ kuzey, $25^{\circ}$ güney paralelleri arasında yer alan Yengeç ve Oğlak dönenceleri kuşağında yetişen kahve ağaçları, yıllık olarak $25-30^{\circ} \mathrm{C}$ sıcaklığa ve $1200-1800 \mathrm{~mm}$ yağışa ihtiyaç duyarlar. Aşırı sıcaklık ve kuraklık ağaçların büyüme sürecini sınırlar (Foto 1). Ağaçlar bu şartların sağlandığı 1600-2800 metre yükseltiye kadar çıkabilirler. Özellikle nemli hava şartları ağacın vejetasyon süresini uzatmaktadır. (Da Matta, vd., 2008: 487). Kireçli toprakları sevmeyen kahve ağaçları organik madde miktarı bakımından zengin topraklarda daha çok gelişirler (thespruce.com/grow-coffee-plants-1902614). Sıcaklık ve yağışa karşı oldukça duyarlı olan kahve ağaçları, küresel 1sınma sebebiyle artan sıcaklıklar karşında olumsuz etkilenmektedir. Bu durum kahve hasat miktarında düşüşler yaşanmasına sebep olmaktadır. Bununla birlikte Afrika’nın değişik ülkelerinde ormanlık alanlarda yetişen bu ağaçlar, burada yaşayan insanların konut alanlarını genişletmek için kesilmektedir. Bu durum dünya kahve üretimi yapan ülkeler için olumsuz bir senaryo oluşturmaktadır (Magrach \&Ghazoul, 2015; Woldermariam, vd., 2002).

Kahve ağacının botanik tanımı ilk defa 1713 yılında Antoine de Jussieu tarafından Jasminum arabicanum olarak yapılmıștır (Crishan, 2017: 2). Tropikal bir bitki olan kahvenin pek çok türü vardır. Fakat buna rağmen iki tür dünya piyasasında tercih edilmektedir. Bunlardan ilki coffee arabica olarak bilinen ve dünya kahve üretiminin \%7580 ile ilk sırada yer alan türdür. Onu \%20'lik bir üretimle coffee robusta takip etmektedir. Coffee arabica’nın fazla tercih edilmesinin sebebi düşük asit oranıdır. İçiminin daha rahat olduğu bu kahve türü genellikle büyük kahve firmaları tarafından daha yüksek fiyata satın alınır. Coffee robusta yağmur ormanlarında yetişen yüksek sıcaklıkların büyüme sürecini sınırladığı bir kahve türüdür. Vietnam, Kongo, Fildişi Sahilleri’nde yetişir. 
Foto 1. Kahve Ağac1

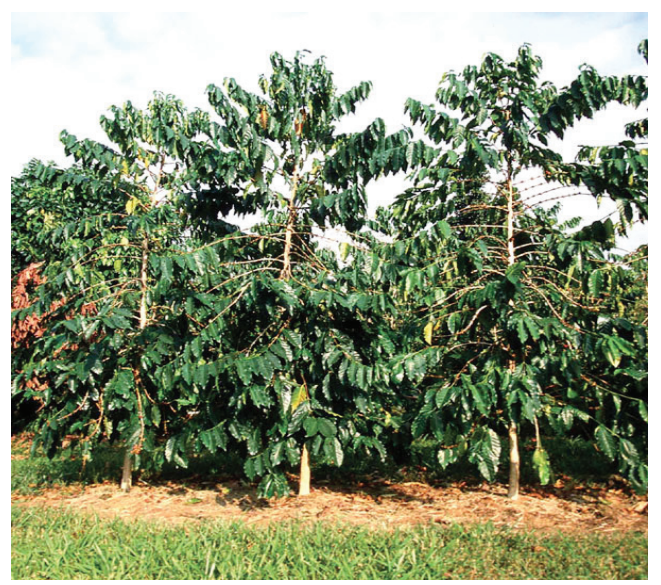

Kaynak: www.wikiwand.com/tr/Kahve

Kahvenin esas anavatanı Etiyopya'dır. Üretiminin en fazla olduğu ülkeler ise Yemen, Etiyopya, Brezilya, Kolombiya, Endonezya ve Vietnam'dır (Harita 1). Etiyopya’nın ekonomisinde kahve oldukça önemli bir rol oynamasına rağmen çekirdeklerinin düşük kalitede olması diğer ülkeler tarafından çok fazla tercih edilmemesine sebep olmaktadır (Bote \& Vos, 2017: 39).

Harita 1. Dünyada Kahve Üretiminin En Fazla Olduğu Ülkeler

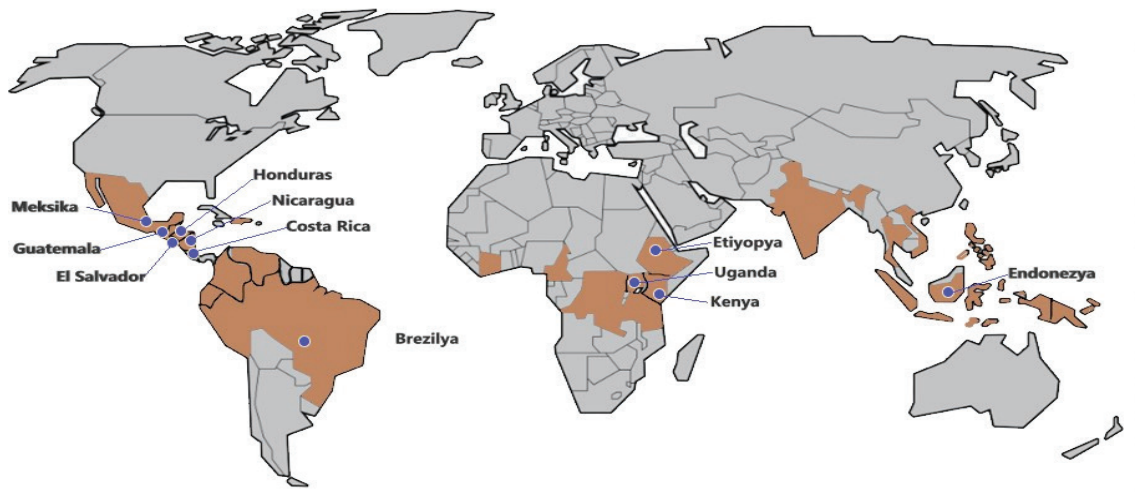

Kaynak: marrone.com.tr/blog/kahve-yetisen-ulkeler'den yararlanarak hazırlanmıştır.

Türkiye iklimsel olarak kahvenin yetişmesine uygun bir ülke değildir. Buna rağmen Akdeniz ikliminin hüküm sürdüğü, yaz sıcaklığının fazla olduğu Mersin ve Anamur 
çevresinde kahve üretimi için çalışmalar yapılsa da bu çalışmalardan yeterli verim alınmamıştır. Bununla birlikte Antalya'da girişimcilerin kişisel çabaları ile Akdeniz Üniversitesi Ziraat Fakültesi iş birliği ile kahve ağaçları ekilmiş, ekilen bu ağaçlardan az bir ürün hasat edilmiştir. Yapılan bu çalışmalar deneme amaçlı olup üretimin yaygınlaşması da hedeflenmektedir (tarımpusulası.com/desteklemeler/3).

\section{TARİHİ COĞRAFYA AÇISINDAN KAHVENINN YOLCULUĞU}

Kahvenin ne zaman bulunduğu hakkında kesin kayıtlar olmamakla beraber, keyif veren bu içecek hakkında mitolojik ve dini birtakım hikayeler mevcuttur. Toplumların yaşantılarına göre şekil alan bu hikayelerde kahve bazen sağlığa yararlı ve içilmesi tavsiye edilen bir içecek iken bazı toplumlarda içilmesine izin verilmeyen hatta bazı zamanlarda şiddetle yasaklanmış olan bir içecek olmuştur. Bununla birlikte tropikal bir bitki olması dolayıyla özellikle Afrika ve daha sonrasında Arap toplumlarında ilk olarak ekmek olarak tüketilen kahve tohumları daha sonrasında kavrularak içeceğe dönüştürülmüş ve bu noktadan sonra kahvenin saltanatı tüm dünyayı sarmıştır.

Harita 2. Kahvenin Yayılışı

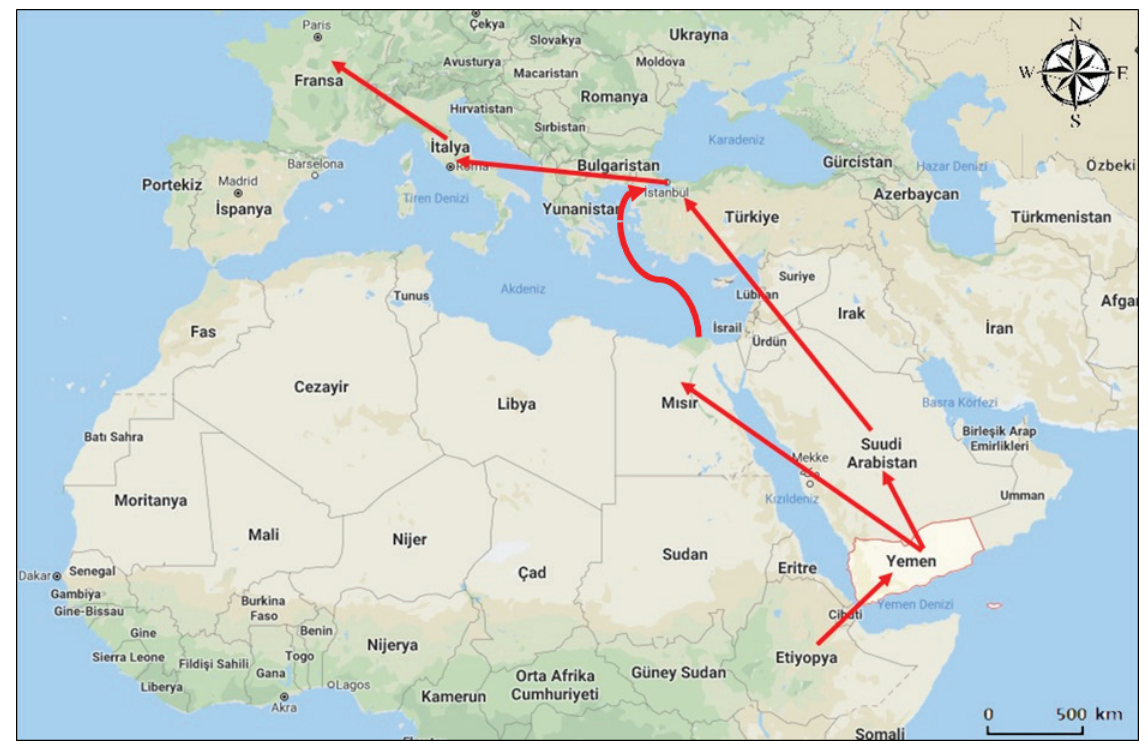

Kaynak: Google Earth Programından Yararlanarak Hazırlanmıştır.

Kahvenin yayılmasında özellikle sufilerin etkisinden çok bahsedilmektedir. Tarikat mensubu olan sufiler kapalı bir topluluk değillerdi. Gündüz halkın içinde yaşar, ibadetlerini gece yaparlardı. Özellikle Yemenli sufiler kendi içlerinde yaptıkları toplantılarda kahveyi tüketmiş ve aynı zamanda gittikleri yerlere de götürerek yayılmasında öncülük etmişlerdir. 
Kahire’de bulunan El-Ezher Üniversitesi’nde eğitim gören Yemenli öğrencilerin içtikleri kahve Kahire’de yayılmaya devam etmiştir. İslam coğrafyası için oldukça önemli bir merkez olan Mekke ve Medine dünyanın dört bir tarafından buraya gelen hacılar için kahvenin tadıldığı ve beraberlerinde ülkelerine götürdükleri önemli bir içecek olmuştur (Tunç, 2014: 24).

Kahvenin Anadolu topraklarına geliş tarihi hakkında tam bir netlik yoktur (Yılmaz, 2017: 571). Müslüman tüccarlar tarafından Yemen, Cidde, Kahire gibi şehirlerden İskenderiye limanını kullanılarak deniz yoluyla İstanbul Eminönü’ne getirildiği ve buradan dă̆ıldığı rivayet edilmektedir (Harita 2). Özellikle Yavuz Sultan Selim'in Misır seferi ile İstanbul'a geldiği de bilinmektedir. Tarihçilerin üzerinde daha çok durdukları nokta ise Yemen Valisi olan Özdemir Paşa'nın getirdiği ve içecek olarak ilk defa kahveyi Kanuni Sultan Süleyman’a tattırdığg yönündedir (Şahbaz, 2007: 7).

Anadolu da çok sevilen kahve Anadolu'dan Avrupa'ya Venedikli tüccarlar tarafindan götürülmüş Fransa ve İtalya'da çok fazla rağbet görmüştür. 1669 y1lında İstanbul'dan Fransa'ya giden Osmanlı sefiri Osman Paşa’nın beraberinde götürdüğü kahve çuvalı kahvenin Avrupa'da yayılmasının başlangıcını oluşturmuştur. Yine Viyana kuşatması sonrasında Türk ordusunun geride bıraktığı kahve çuvalları o zaman kadar kahveyi tanımayan Viyanalılar için bir daha vazgeçemeyecekleri bir içeceğe kavuşmalarına olanak tanımıştı.16 ve 19. yüzyıllar arasında Avrupalıların egzotik ürünlere karşı ilgileri artmış, özellikle İngilizler sömürge ülkeleri kullanarak kahve ticaretinin denetimini ele geçirmişlerdi (Kaplan, 2011).

\section{DAVRANIŞSAL COĞRAFYA AÇISINDAN KAHVEHANELER}

Davranışsal coğrafya mekân üzerinde gerçekleşen insan hareketlerini coğrafyanın prensiplerine göre inceleyen beşerî coğrafyanın bir dalıdır (Temurçin ve Keçeli, 2015: 118; Tümertekin ve Özgüç, 2015). Bu anlamda coğrafyanın esas konusu olan mekân kavramı sadece fiziki olarak değil davranışsal olarak da kendine yer bulmuştur. Günümüz insanının ev ve iş yerinden ayrı üçüncü mekân olarak tanımladığı ve yaşadığı çevreyi zihin haritalarında farklı tasarladığ (Yavan ve Anlı, 2019). Bu etkiler, kişilerin cinsiyetine, yaşına, mesleğine, eğitim düzeyine göre değişebilmektedir. 
Foto 2. Osmanlıda Halk Kahvehaneleri

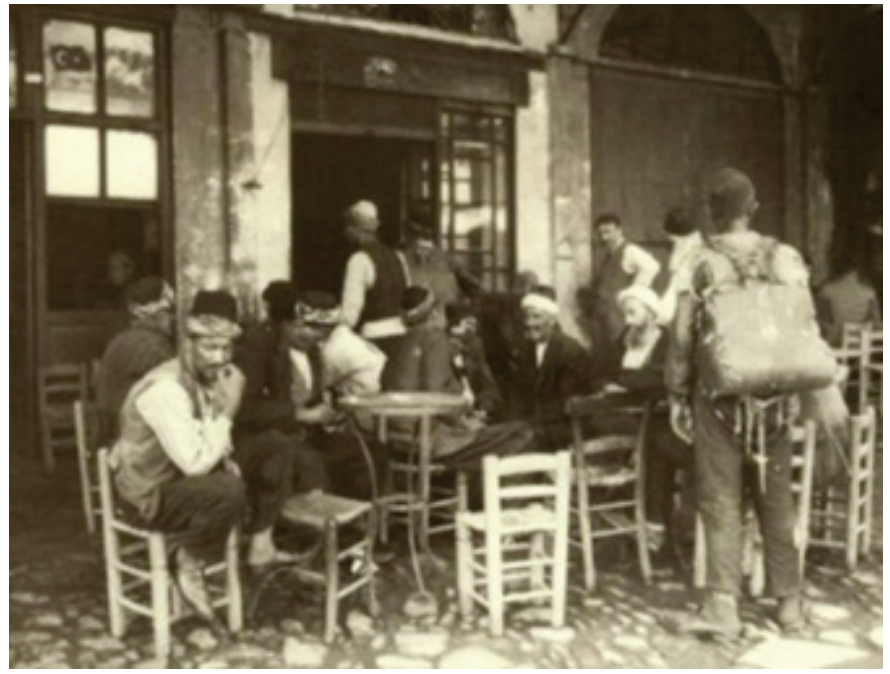

Kaynak: www.ekrembugraekinci.com/makale.asp?id=638

Yaklaşık olarak 500 yıldır bu topraklarda olan kahvenin içildiği mekanlar en az kahvenin kendisi kadar önemli olmuştur. Osmanlı devletinde bulunan kahvehaneler sadece kahvenin içildiği bir yer değil aynı zamanda kapalı bir toplum olan Osmanlıda, insanların sosyalleşecekleri bir alana dönüşmüștür (Foto 2). Kanuni Sultan Süleyman zamanının Şeyhülislamı olan Ebu Suud Efendi’nin verdiği fetvalarla konulan kahve yasağı, III. Murad zamanında Şeyhülislam Bostanzade'nin verdiği fetvalarla ortadan kalkmıştı (Ürer, 2010). Osmanlı arşivlerinde kahvehanelerde yapılan sohbetlerden "devlet sohbeti" olarak bahsedilmiş, bu sohbetler esnasında çıkan tartışmalar ile kahvehaneler bir süre sonra yetkililerin hedefi haline gelmiştir (Çaksu, 2019: 371). Yasaklı dönemlerinde dahil kahvehaneye gitmeye devam eden insanların yoğun talepleri kahvehanelerin tekrar açılmasını sağlamıştı.

Açılan kahvehaneler bir süre sonra farklı mesleklerin toplandı̆̆ gruplar şeklinde dağılmıştır. Tulumbacı, balıkçı, esnaf, yeniçeri, kuşçu, meddah, aşık kahvehaneleri gibi (Foto 2).

Osmanlı Döneminde insanların evden sonra ikinci mekân olarak belirlediği kahvehaneler oldukça popüler olmuştur. Kendi meslektaşları ile bir araya gelen kişiler bir süre sonra kendi kuralları olan lonca teşkilatına benzeyen oluşumları bu mekanlarda meydana getirmişlerdir. Yine loncalarda oluşan birtakım kurallar bazı esnaf kahvehanelerinde de oluşmaya başlamış, kahvehaneye giden insanlar toplumsal olan bu kurallara dikkat etmek durumunda kalmışlardır (Çağlayan, 2012; Çoşkun ve Orhan, 2019). Zaman içinde kahvehanelerin çevresinde cami, dükkân gibi sosyal donatıların oluşmaya başlaması bu 
mekanların bulundukları şehirlerin ya da kasabaların merkezine yerleşmesini sağlamıştı. Yine kahvehanelerde maskulen bir yapı oluşturmuş, kadınların girmesinin yasak olduğu sadece erkek egemen bir topluluğun olmasına zemin hazırlamıştı (Kanbir, 2018). Tüm bu özellikler insanların kahvehane kültürü adı verilen yazılı olmayan fakat toplum tarafından kabul edilmiş olan kuralları benimsemesine sebep olmuş zaman içinde bu kurallar insan davranışlarını da etkilemiştir.

İstanbul'u ziyaret eden batılı seyyahlar eserlerinde kahvehanelerden çok fazla bahsetmişlerdir. Özellikle 1672-1675 yılları arasında İstanbul'da bulunan Fransız seyyah Galland kendi kişisel gözlemlerini bir arkadaşına şu şekilde ifade etmiştir: "İstanbul'da yaşayan insanlardan en zengininden, en fakirine Türk'ünden, Rum’una, Ermeni'sinden, Yahudi'sine kadar biri sabah yemeğinden sonra diğeri öğleden sonra olmak üzere kahve içmeyen ne bir ev ne de bir aile vardır" (Ağıldere, 2019: 23). 1554 yılında İstanbul'da ilk kahvehanelerin açıldığı tarihten itibaren dolup taşan bu mekanlar 19. yüzyılın ikinci yarısından sonra edebiyat çevrelerinin de rağbet ettiği yerler olmuştur. Kahvehaneden kıraathaneye geçiş bu şekilde başlamış kahve adı altında insanlar yeni yazdıkları şiirleri, kitapları arkadaş ve çevrelerine burada okumuş ve tanıtmışlardı. Bu sebepten dolayı bu kahvehanelere o dönemde mektebi irfan adı verilmişti (Yıldız, 2002: 7; Balkaya, 2013). İlk çıktığında sadece zenginlerin alıp içeceği bir içecek olan kahve, kahvehanelerin açılması ile halkın arasında da yayılmıştır. Evliya Çelebi'ye göre sadece İstanbul'da kahvehanelerin sayısı 200'ü bulmuştur. 1500'lü yıllarda İstanbul'unun nüfusunun 100.000-120.000 arasında olduğu düşünüldüğünde 200 oldukça ciddi bir rakamdır (Koç, 2010: 195).

Geçmişten günümüze artarak devam eden kahvehane kültürü modern kafelerin açılması ile kabuk değiştirmiş, özellikle yeni nesli kendine çekmiştir. Yapımının kolay olması, ucuz olması, sosyalleşme için ortam hazırlaması kahvenin tüketimini artırmış, kahve mekanlarının artmasını sağlamıştır (Avcıkurt, vd., 2019).

\section{KÜLTÜREL COĞRAFYA AÇISINDAN KAHVENIN TÜRK KÜLTÜRÜNDEKİ YERI}

Toplulukları millet yapan en önemli unsur tarih boyunca beraber yaşamalarından kaynaklanan gelenek, görenek, örf ve adetleridir (Atlı, 2018). Toplumun yapı taşlarını oluşturan bu değerler kuşaklar boyu aktarılarak milletin bir arada yaşamasını sağlar, bir nevi toplumsal çimento görevini üstlenir. Tarihte yer alan kadim milletler arasında olan Türkler, bir arada yaşamanın getirdiği çok köklü kültürel bir zenginliğe sahiptir.

Bu kültürel zenginliğin içinde yer alan kahve, Türk topraklarına 1500’lü yıllarda gelmiş fakat diğer ülkelerden farklı sunumu ve pişirme şekilleri ile “Türk Kahvesi” adı altında 2013 yılında UNESCO tarafından tescillenmiştir. UNESCO'nun tescillediği ve somut olmayan kültürel miras değerleri içinde yer alan kahve tescillenen ilkiçecektir (Aşık, 2017:310; Çaksu, 2019: 379; turkkahvesidernegi.org/index.php?icerik=hakkimizda\&ttkad=menuactive). 
Bir kahvenin 40 yıl hatırının olduğu bu topraklar bu içeceğe ayrı bir önem vermiş, günün her saatinde ikram edilmiş ve içilmiştir. Köylünün kahve cezvesi gösterişsizdir ama konukları ağırlamak için sürekli kaynar anlamında söylenen "Köylünün kahve cezvesi karaca ama sürece" atasözü ile de toplumun en alt kesimlerinden itibaren kahvenin misafirperverliğin simgesi olduğunu vurgulamıştır. "Sunulmadı bana kahve deme sen, nasibin varsa gelir Yemen'den”, Kahve gibi aziz ol, telvesi gibi zengin ol” şeklindeki ifadeler hayata dair tecrübeleri bilgece ifade etmişlerdir (Güral, 1999: 72).

İnsan hayatının en önemli anı olan kız istemenin simgesi de kahvedir. Sözsüz bir iletişim aracı olan kahvenin kız isteme ritüelinde ikram edilmesi kız tarafının kızını vermeyi kabul ettiğinin bir işareti olarak sayılmaktadır. Türk kültüründe köpüklü kahve daha makbul olup, bol köpüklü kahve Osmanlıda payitaht kahvesi olarak adlandırılmıştır. Kahvenin ikram edildiği fincanların şekli kültürümüzde farklı anlamlar ifade etmektedir. Osmanlılar Döneminde padişahların kahve içtikleri fincanlar ayaklı bir şekilde yapılırken, şehzadelerin fincanları ayaksız olurdu. Bununla birlikte kırmızı rengi payitahtı ifade etmekteyken, Osmanlı da din adamlarının kahve içtiği fincanlar genellikle yeşil renkte olurdu (Bulduk ve Tufan, 2007: 301)

Türkçe de günlük hayat yaşantısı içinde kahve kelimesi çok fazla kullanılmaktadır. Türk kültüründe kahvaltı, kahveden önce yenen yemek anlamında kullanılır. Avrupalıların kestane dediği renk Türkiye’de kahverengi olarak bilinmektedir. Yüzlerce yıldır halk arasında söylenen ve kuşaktan kuşağa aktarılan kadim türkülerimiz içinde kahve çok sık olarak dile getirilmektedir (Kartal, 2017: 223).

İthal bir ürün olan kahvenin pahalı olması, kahve ithalatında birtakım sorunların da yaşanmasına sebep olmuştu. Özellikle I. Dünya Savaşı, Kurtuluş Savaşı gibi savaş dönemlerinde yokluk çeken ve aynı zamanda kahveden vazgeçemeyen halk adı kahve olan fakat içinde kahve bitkisi olmayan içecekleri üretmişti. Bu kahveler arasında kenger, menengiç, çörek otu ve mırra kahveleri sayılabilmektedir (Kaya ve Toker, 2019).

Kenger (Gundelia tournefortii), Doğu Anadolu Bölgesi’nde daha çok yayılış gösteren Güneydoğu Anadolu, Akdeniz Bölgesi’nde yetişen papatyagiller familyasına ait çok yıllık bir bitkidir. Doğu Anadolu Bölgesi’nde yemek olarak tüketilen bu bitki, Ege ve Akdeniz Bölgelerinde daha çok baş kısmının kurutulup, ögüüülmesi ile kahve olarak tüketilen bir içeceğe dönüştürülmüştür (Konak, vd., 2017: 102).

Yaklaşık olarak üçyüzbin yıldan beri faydası bilinen hakkında hadisler bulunan çörek otu (Nigella Sativa L) halk arasında şifalı bir bitki olarak bilinmektedir. Tıbbi açıdan çok fazla faydası bulunan, üzerinde akademik anlamda pek çok araştırma yapılan çörek otu besin maddeleri bakımından zengin, killi ve kumlu olmayan topraklarda yetişmektedir (Ulus, vd., 2018: 25). Genellikle sıcak iklim koşullarını seven bu bitkiye ülkemizde Ege ve Akdeniz ve Güneydoğu Anadolu’da Bölgesinde rastlanmaktadır. Çörek otu tohumlarının kavrulup, ögütülmesi ile kahve olarak tüketilmektedir. Türkiye’de Denizli ve Burdur yöresinde çörek otu kahvesi tüketilmektedir. Pişirme tekniği olarak Türk kahvesi ile aynı olan içine bir 
miktar kahve de karıştırılarak yapılan çörek otu kahvesi şifalı etkisi nedeniyle de tercih edilmektedir.

Menengiç (Pistacia terebinthus) sakız ağacıgiller familyasına ait olan Akdeniz iklimine ait olan bölgelerde yetişen Türkiye'de Akdeniz ve Güneydoğu Anadolu Bölgeleri'nde yetişen bir bitkidir (Hayoğlu, vd., 2010: 58). Kuru ve taşlık arazide yetişen menengiç, antep fıstığı ağacının aşılanmamış bir halidir. Menengiç ağacının meyveleri toplanarak kavrulur öğütülerek kahve haline getirilir. Protein, yağ ve lif açısından oldukça zengin olan ve Türk kahvesinden farklı olarak sütle hazırlanan menengiç kahvesinin içimi daha yumuşaktır. Özellikle Gaziantep ve çevresinde tüketilmektedir.

Tam olarak hangi yöreye ait olduğu bilinmeyen dibek kahvesi, dibek adı verilen iki taş arasında kavrulmuş kahve çekirdeklerinin elle dövülmesi sonucunda yapılan kahve türüdür. Elle dövülerek ögütüldüğü için taneleri diğer kahvelere göre daha kalın olan dibek kahvesinin dövülme işlemi sırasında kahvenin içindeki aromatik yağlar ortaya çıkmakta, kahve daha köpüklü olmaktadır. Deveci’nin yaptığı araştırmada dibek kahvesi 1877 yılından itibaren Kırklareli ve civarında içilmeye devam etmiştir (Deveci, 2020: 54).

Ülkemizde daha çok Güneydoğu Anadolu Bölgesi’nde içilen mırra kahvesi kaküle (Elettaria cardamomum) adı verilen bir çeşit baharattan yapılmaktadır. Kaküle, daha çok Hindistan, Malezya, Tibet gibi uzak doğu ülkelerinde bol miktarda yetiştirilen ve tüketilen, içinde A ve C mineralleri bakımından zengin olan bir bitkidir. Arap coğrafyasında çok sevilen ve tüketilen mırra kahvesi Şanlıurfa, Gaziantep, Mardin illerinde tüketilir. Arapça "mur" acı anlamına gelmektedir. Kahvenin yoğun ve acı tadı sebebiyle daha küçük fincanlarda ikram edilmektedir.

\section{TÜKETIMM COĞRAFYASI AÇISINDAN TÜRKİYE'DE KAHVE}

Ekonomik coğrafyanın araştırma alanlarından biri tüketim coğrafyasıdır. Kazanç sağlayan her türlü mal ve hizmet ekonomik coğrafyanın alanına girmektedir. Zaman içinde değişen toplumsal ve ekonomik süreçlerin neler olduğu, bu süreçleri küresel ve yerel dinamikleri nasıl etkilediklerini coğrafyanın mekân ve insan kavramı perspektifinde inceleyen araştırma alanı tüketim coğrafyasıdır (Doğanay ve Çavuş, 2011: 4).

İthal bir ürün olan kahve, ihracatı yapan ülkeler için kar anlamına gelirken, ithalat yapan ülkelere için ise sosyal ve kültürel katkı anlamına gelmektedir. Dünyada yıllık olarak kahve üretimi 8 milyon tondur. Yillık toplam ticari değeri 100 milyar \$ olan kahve petrolden sonra en önemli hammadde sınıfına girmektedir. Dünyada en fazla kahve tüketimi olan ülke kişi başı yıllık olarak 9,6 kg ile Finlandiya iken onu Norveç ve Hollanda takip etmektedir. Türkiye 'de kişi başı kahve tüketimi yıllık olarak 0,92 kg olarak belirlenmiştir (ICO, 2018). 
Tablo 1. Türkiye’nin Yıl Bazında İthalat Değerleri (Bin \$)

\begin{tabular}{|l|c|c|c|}
\hline Yıllar & $\mathbf{2 0 1 6}$ & $\mathbf{2 0 1 7}$ & $\mathbf{2 0 1 8}$ \\
\hline İthalat Rakamları & 130.503 & 191.808 & 186.584 \\
\hline
\end{tabular}

Kaynak: WTO, 2019

ICO’ nun verilerine göre Türkiye’nin kahve ithalatında da 2016-2018 yılları arasında bir artış görülmesine rağmen kahve tüketiminin Avrupa ülkeleri içindeki payının az olduğu görülmektedir. 2016-2018 yılları arasında kahve tüketimi \%43 oranında artmıştır.

Grafik 1. Türkiye’nin Yıl Bazında İthalat Değerleri (Bin \$)

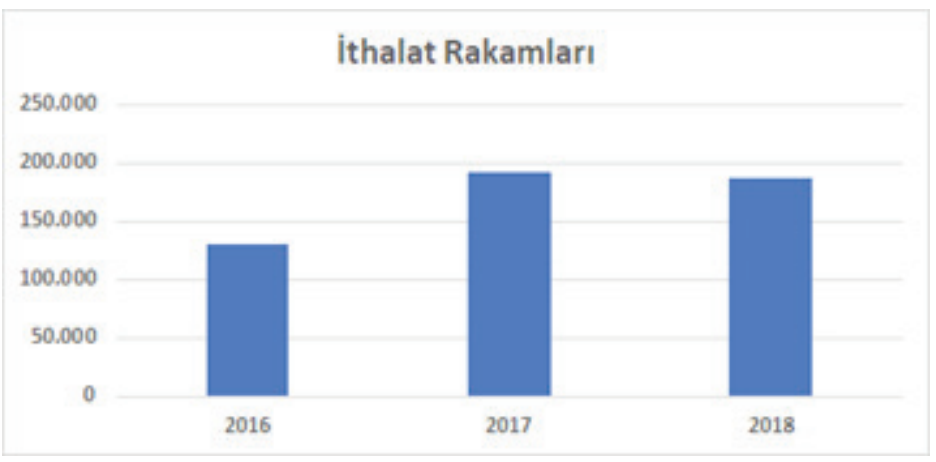

Avrupa'da günün her saatinde kahve içme alışkanlığının olması tüketimi artırmıştır. Türkiyede tüketimin Avrupa ülkelerine göre bu kadar düşük olmasının temelinde Türk insanı için özellikle Türk kahvesinin belirli zamanlarda içilme alışkanlığından kaynaklanmaktadır. Arkadaş toplantılarında daha çok kahve tüketimi olurken insanlar kahveyi daha çok kahve mekanlarında içmeyi tercih etmektedirler. Bununla birlikte Türk kahvesinin yapımının diğer kahvelere göre zor olması, taşınabilir olmaması insanları daha çok diğer granül kahveleri tüketmeye yöneltmektedir (Aşık, 2017: 321). Türkiye’de özellikle büyük şehirlerde açılan çok sayıdaki kahve mekanları genç nesli kendisine çekerek kahve tüketiminin artmasını sağlamıştır. Özellikle büyük kahve şirketleri İstanbul, Ankara, İzmir, Bursa gibi büyük şehirlerde bayi sayılarını artırmışlardır. Burada en önemli faktör büyük şehirlerin coğrafi olarak ulaşılabilir olması, nüfusun burada fazla olması çok sayıda üniversiteye ve dolayısıyla genç bir nüfusa sahip olmalardır.

Son dönemlerde farklı disiplinlerde yerel ürünler ve bu ürünlerin ticari ve toplumsal etkileri üzerinde çalışmalar artmıştır (Yavan ve Anlı, 2018: 1371). Pek çok firma yaşanan yoğun rekabet ortamında kendilerine bir yer bulabilmek ve farklı olabilmek amacıyla yeni ürün ve hizmet arayışı içine girmişlerdir. Bu bağlamda somut olmayan kültürel miras 
listesine içinde yer alan, geleneksel ve aynı zamanda sürdürülebilir olan ürünleri ön plana çıkarmak ve bu ürünler ile ilgili farkındalık oluşturmak ticari değeri olan bir satış tekniği olarak görülmektedir (Çevik ve Saçılık, 2016: 231).

Avrupa ülkelerine göre Türk kahvesinin her ne kadar tüketimi az olsa da pişirme ve sunum tekniklerinin değişmemesine rağmen kahvenin satışını artmaktadır. Bu artıştaki en önemli faktör hizmet sektöründeki değişimdir. Ürünleri hizmetle zenginleştiren ve kişiselleştirme derecesini artıran ekonomi türüne deneyim ekonomisi adı verilmektedir. Yani tarladaki meta olan kahvenin ögütülerek güzel bir mekânda tüketiciye ismiyle hitap edilerek satışının yapıldığı süreç deneyim ekonomisinin alanına girmektedir (Yavan ve Anl, 2019: 101; marketingturkiye.com.tr/koseyazilari/deneyim-ekonomisi/). Deneyim ekonomisi perspektifinde yapılan insanların bazen yapımına da dahil olduğu festivallerde hizmet sektörü içinde değerlendirilen ve ürünlerin satışını artıran aktiviteler olarak değerlendirilmektedir. Son dönemlerde İstanbul, Ankara, İzmir, Antalya, Kocaeli ve Elazığ’da açılan ve halkın yoğun katılımının sağlandığı Türk Kahvesi festivallerinin farklı bir içecek deneyimi yaşatması ve farkındalığı artırması açısından önemi büyüktür.

Kahvenin sunulduğu mekanlarda yaşanan değişim ve gelişimler de kahveye olan talebin artmasını sağlayan unsurlardır. Ritzer tüketim toplumlarının amacının insanların rahat hissettikleri büyülü bir ortamlarda tüketimin artırılması olduğunu ifade etmiştir (Aşık, 2017:310; Acar, vd., 2019: 143; Özgen ve Karabacak, 2013: 120). Tüm dünyada olduğu gibi Türkiye'de de son 20 yılda açılan kahve mekanları kahveye olan talebin artmasına zemin hazırlamıştır. Özellikle Starbucks gibi marka yönetiminin profesyonel bir şekilde yapıldığı kurumsal firmalar tüm dünyada kahve denince akla gelen ve farklı ülkelere ait kahvelerin deneyimlendiği bir mekân olması açısından önemlidir (Kodak, 2011; Kuzucu, 201; Uran, 2018).

Küreselleşen dünyada din, dil, ırk, kültür gibi birtakım yerel unsurlar birleşerek medeniyetin ortak paydasını oluşturmuşlardır. Dünya ticaretinde ülkeler kendi milli değerlerini hem dünyaya tanıtmak hem de bu değerleri birer turizm ürününe dönüştürmek için adeta yarış halindedirler (Fendal, 2012). Bu bağlamada Türkiyede ise daha çok yerelliğin ön plana çıktığı Kahve Dünyası, Gönül Kahvesi gibi isimlerle açılmış olan firmalar Türk Kahvesi çatısı altında satışlarını gerçekleştirmektedirler. Türk Kahvesinin yanında her ne kadar farklı kahve türleri ve tatlıları sunulsa da konsept olarak Türk misafirperverliğini ön plana alınması, tüketiciye ev ortamı oluşturması ve yerelliğin ön plana çıkması bu tarz firmaları diğerlerinden ayırmaktadır (Yavan ve Anlı, 2019: 122).

Bununla birlikte kenger, menegiç, çörek otu gibi coğrafi olarak Türkiye’nin değişik bölgelerinde yetişen bitkilerin tohumlarının kurutulup öğütülmesi ile yapılan kahveler de son zamanlarda tercih edilmektedir. 


\section{SONUÇ}

İlk defa kim ve hangi ülke tarafından içecek haline getirildiği tam olarak bilinmeyen ve hakkında çok fazla rivayet olan kahvenin Afrika'dan başlayan serüveni Arap Yarımadasını takip eden coğrafyadan Anadolu'ya uzanmıştır. Sosyalleşmenin, dostluğun ve misafirperverliğin somut bir göstergesi olan kahve Türk insanı tarafından çok sevilmiş adına türküler yakılmış, kültürel ritüellerin temeline yerleştirilmiştir.

Petrolden sonra en fazla ticareti yapılan ve dünyada sudan sonra en fazla içilen içecek olan kahvenin Türk Kahvesi olarak tescillenmesi ancak 2013 yllında olmuştur. UNESCO tarafından tescillenen ilk sıvı olma özelliği ile de önemini korumaktadır. Türkiye’de yetişmeyen ve dışarıdan ithal edilen bir ürün olan kahvenin Türk topraklarına gelişi yaklaşı olarak 500 yıllık bir sürece tekabül eder. Buna rağmen ICO’nun verilerine göre 2012-2013 yılında kişi başına tüketim 590 gr. iken 2015-2016 yllında bu oran 920 gra ulaşmıştır.

Farklı pişirme ve sunum teknikleri ile dünyada yer alan diğer kahvelerden ayrılan Türk Kahvesi günümüzde yeni nesil kahveler arasında kendisine yer bulmakta ve genç nesil arasında da tercih edilmektedir. Türk kahvesinin pişirilmesi ve sunumu Türkiye’de bölgelere göre çok fazla değişmemesine rağmen, ithal bir ürün olan kahveye alternatif olarak farklı coğrafi bölgelerde yetişen menengiç, çörek otu, kengir gibi bitki tohumlarının kurutulup öğütülmesi ile elde edilen kahve türleri halk arasında sevilip yaygınlaşmaya başlamıştır. Türkiye iklim koşullarında her bölgede yetişen, ucuz olan, damak tadı olarak Türk insanının kendine göre şekillendirdiği bu bitki kahveleri Türk kahvesine alternatif olarak tercih edilmektedir. 


\section{KAYNAKÇA}

Ağıldere, S. (2019). Batılı Seyyahların Gözünden İstanbul ve Cezayir’de Kahve ve Kahvehane Kültürü (17. Yy- 19. Yy). Milli Folklor. Sayı, 122, 14-28

Akarçay, Erhan (2012). Kah Kahvehane Kah Cafe: Küreselleşen Eskişehir'de Kahve Tüketimi Üzerine Kurumsal Bir Giriş, Aynalı Labirent Küreselleşen Kentte Tüketim İçinde (Ed.: Ali Ergur), Galatasaray Üniversitesi İletişim Dergisi, 2, 181-202

Anlı, C., Yavan, N. (2018). Tüketim Mekanlarının Üretimi: Simit ve Simit Sarayı Örneği. TÜCAUM 30. Y1l Uluslararası Coğrafya Sempozyumu. 3-6 Ekim 2018, 1371-1372

Aşık, N. (2017). Değişen Kahve Tüketim Alışkanlıkları ve Türk Kahvesi Üzerine Bir Araştırma. Journal of Tourism and Gastronomy Studies. Say1,5, 310-325.

Atlı, F. (2018). Kahve Pazarlaması ve Türk Kahvesinin Ekonomik, Sosyal ve Kültürel Özelliklerinin Değerlendirilmesi. Akademik Sosyal Araştırmalar Dergisi. Sayı, 84, 413-424

Balcı, F. (2019). Cezveden Kültüre 40 Yıl: Türk Kahvesi ve Geleneği. Akademik Sosyal Araştırmalar Dergisi. Sayı, $87,315-328$

Balkaya, A. (2013). Mekân Politikası Bağlamında Âşık Kahvehaneleri ve Âşık Üzerinde Kimi Fonksiyonları. Turkish Studies International Periodical For The Languages, Literature and History of Turkish or Turkic. Say1, 8, 881-889

Bote, A., Bose, J. (2017). Tree Management And Enviromental Conditions Affect Coffe(Coffe Arabica L.)Bean Quantility. Wageningen Journal Of Life Sience. Volumme 86, 39-46

Bulduk, S., Süren, T. (2007). Türk Mutfak Kültüründe Kahve. 38.Icanas 38. Uluslararası Asya ve Kuzey Afrika Çalışmaları Kongresi, 10-15 Eylül 2007, Ankara

Çağlayan, S. (2012). Anadolu’nun İlk Kamusal Mekânı: Kahvehane. Muğla Sıtkı Koçman Üniversitesi Sosyal Bilimler Enstitüsü Dergisi, Sayı 29, 95-110

Çaksu, A. (2019). Bir Siyasî İçecek Olarak Türk Kahvesi. SEFAD. Sayı, 41, 369-386

Da Matta, F., Ronchi, C., Maestry, M., Barros, R. (2008). Ecophysiology Of Coffee Growth And Production. Rewiew. 19(4), 485-510

Deveci, B. (2020). Kırklareli Dibek Kahvehanesinin Tercih Edilme Sebeplerinin Belirlenmesi. Türk Turizm Araştırmaları Dergisi. 4(1), 50-66

Diker, O., Deniz, T. (2017). Coğrafya ve Tarih Perspektifinden Somut Kültürel Miras ve Türkiye. Pegem Akademi: Ankara

Doğanay, H., Çavuş, A. (2016). Türkiye Ekonomik Coğrafyası. Pegem Akademi: Ankara

Ergün, A. (2017). Kursal Alanda Kahvehanelerin Rolü: Tokat İli Merkez İlçe Örneği. Gazi Osman Paşa Üniversitesi. Sosyal Bilimler Üniversitesi. Basılmamış Yüksek Lisans Tezi. Tokat.

Fendal, D. (2012). Türkiye'deki Kahve ve Mutfak Kültürünün Dönüşümü Üzerinden Küreselleşme Sürecinde Küresel ve Yerel Kültürün Etkileşim ve Eklemlenişi. Galatasaray Üniversitesi iletişim Dergisi. 147-180 
Güral, S. (1999). Türk Kültüründe Kahvenin Yeri. Anadolu Üniversitesi. Sosyal Bilimler Enstitüsü. Basılmamış Yüksek Lisans Tezi. Eskişehir.

Hayoğlu, İ., İzoli, G., Gümüş, A., Göncü, B., Çevik, G. (2010). Menengicin Şekerleme Üretiminde Kullanım Olanakları. HR.Ü.Z.F. Dergisi, 14(4): 57-62

Kartal, S.G. (2017). Hüseyin Rahmi Gürpınar’n Eserlerinde Kahve ve Kahve Kültürü. Folklor Edebiyat Dergisi. Sayı, 91, 211-236

Kanbir, F. (2018). Cinsiyetçi Sosyalleşme Mekânları: Siirt Kent Kahvehaneleri Örneği. Uluslararası Sosyal Araştırmalar Dergisi. Sayı, 60, 641-647

Kaya, G., Toker, S. (2019). Kahve Tüketim Alışkanlıklarının İncelenmesi: İstanbul Örneği. International Journal of Economics, Politics, Humanities \& Social Sciences. Sayı, 2, 146-164

Koç, Y. (2010). Türkiye Araştırmaları Literatür Dergisi, Sayı 16, 171-199

Kodak, D. (2011). Postmodernite Bağlamında Bireyselleşme ve Marka İlişkisi: Sinema Filmlerinde Starbucks Coffee Tüketicilerinin Kimlik Analizi. Maltepe Üniversitesi Sosyal Bilimler Enstitüsü. Basılmamış Yükssek Lisans Tezi. İstanbul

Konak, M., Ateş, M., Şahan, Y. (2017). Yenilebilir Yabani Bitki Gundelia tournefortii’nin Antioksidan Özelliklerinin Belirlenmesi U. Ü. Ziraat Fakültesi Dergisi, Sayı 2, 101-108

Kuzucu, E. (2019). Hizmet Sektöründe Müşterinin Memnuniyetinin Pazarlamaya Etkisi; Starbucks, Caffe Nero ve Kahve Dünyası Örneği. Maltepe Üniversitesi. Sosyal Bilimler Enstitüsü. Basılmamış Yüksek Lisans Tezi. İstanbul

Magrach, A., Ghazoul, J. (2015). Climate and Pest-Driven Geographic Shifts in Global Coffee Production: Implications for Forest Cover, Biodiversity and Carbon Storage. Climate and Pest-Driven Geographic Shifts in Global Coffee Production. 1-15

Ogün, Ç., Orhan, F. (2019). Kültürel İncelemelere Coğrafi Bir Katkı: Erzincan'da Kahvehanelerin Mekânsal Özellikleri. Atatürk Üniversitesi Sosyal Bilimler Enstitüsü Dergisi Sayı, 23, 577-604

Onurlubaş, E., Taşdan, K. (2017). Geleneksel Ürün Tüketimini Etkileyen Faktörler Üzerine Bir Araştırma. AİBÜ Sosyal Bilimler Enstitüsü Dergisi, Sayı: 17, 115-132

Özgürel, G. (2018). Kültürel Mirasa Bir Bakış: Marmaris Örneği. Journal of Social and Humanities Sience Research.Sayı, 5, 4894-4906

Özkan, Ç. (2020). Sürdürülebilir Gastronomi Turizmi Kapsamında Somut Olmayan Kültürel Miras Unsuru: Hıdırellez Pilavı Üzerine Bir Araştırma. Türk Turizm Araştırmaları Dergisi. Sayı, 4, 371-384

Saçılık, M., Çevik, S. (2016). Somut Olmayan Kültürel Miras Unsurlarının Yenilikçi Turizm Ürünlerine Dönüştürülmesi: Bir Örnek Olay İncelemesi. The Journal of Academic Social Science Studies. Sayı, 47, 331-341

Şahbaz, S. (2007). Geçmişten Günümüze Kahvehaneler ve Kahvehanelerin Sosyal Yaşamdaki Yeri ve Önemi: Aydın Merkez Örneği. Adnan Menderes Üniversitesi Sosyal Bilimler Enstitüsü. Basılmamış Yüksek Lisans Tezi, Aydin 
Temurçin, K., Keçeli, K. (2015). Bir Davranışsal Coğrafya Çalışması: Isparta Şehri Örneğinde Uluslararası Öğrencilerin Kentsel Mekân Algısı. SDÜ Fen Edebiyat Fakültesi Sosyal Bilimler Dergisi, Sayı: 36, 117-138.

Tunç, Ş. (2017). Osmanlı Payitahtında Kahvehane ve Kahvehane Kültürünün Yeri. İstanbul Üniversitesi Sosyal Bilimler Enstitüsü. Basılmamış Yüksek Lisans Tezi, İstanbul

Ulus, C., Kaya, P., Taşcı, B. (2018). Çörek Otu Tohumunun Kimyasal Bileşimi ve İnsan Sağlığındaki Yeri. Samsun Sağ Bil Dergisi, 3(1), 25-29

Ulusoy, K. (2011). Türk Toplum Hayatında Yaşatılan Kahve ve Kahvehane Kültürü. Milli Folklor Dergisi, Sayı, $80,159-169$

Ürer, H. (2010). Osmanlı'da Kahve/Kahvehane Kültürü ve Salihli’den Bir Kahvehane Örneği "Himaye-İ Etfal. Sanat Tarihi Dergisi. Say1, 19, 1-26

Yalap, H. (2017). Klasik Türk Edebiyatı Işı̆̆ında Edebiyat Kültür Tarihimizde Kahve ve Kahvehaneler. İnsan ve Toplum Bilimleri Araştırma Dergisi. Sayı, 6, 1907-1930

Yavan, N., Anlı, C. (2019). Deneyim Yaratmada Mekânın Rolü: Starbucks ve Kahve Dünyası̉nın Deneyim Ekonomisi ve Üçüncü Yer Bakımından Analizi. Gaziantep University Journal of Social Sciences. Sayı, 18, $100-132$

Yıldız, C. (1996). Kahvehanelerin Sosyal Hayattaki Yeri. Firat Üniversitesi Sosyal Bilimler Dergisi. Cilt 8, 1-38

Yılmaz, G. (2017). Nev'î-Zâde Atâyî, Subhizâde Feyzî ve Aynînin Sâkînâmelerinden Hareketle Kahvenin Osmanlı Toplumundaki 300 Yıllık Değişimi. Atatürk Üniversitesi Türk Dili ve Edebiyatı Araştırmaları / Makaleler. 571-583

www. thespruce.com/grow-coffee-plants-1902614 (Erişim Tarihi, 4.02.2020).

www. marketingturkiye.com.tr/koseyazilari/deneyim-ekonomisi (Erişim Tarihi, 4.02.2020).

www. tdk. gov.tr (Erişim Tarihi, 4.02.2020).

www. tarımpusulası.com/desteklemeler (Erişim Tarihi, 4.02.2020). 